\title{
First Data on Distribution and Biology of Squalus blainvillei (Risso, 1826) from the Eastern Mediterranean Sea
}

\author{
L. Sion, G. D'Onghia and A. Tursi \\ Department of Zoology, University of Bari \\ Via Orabona, 4 - 70125 Bari, Italy \\ Ch. Mytilineou \\ National Centre for Marine Research \\ Aghios Kosmas, Hellinikon, 16604, Greece
}

\begin{abstract}
Longnose spurdog Squalus blainvillei was sampled along the Greek coasts of the northern Ionian Sea during September-October 1999 and April 2000. A commercial motor powered vessel, equipped with a bottom trawl net with stretched mesh size of $20 \mathrm{~mm}$ in the codend, was used. The hauls were carried out from dawn to dusk between 300 and $1200 \mathrm{~m}$ depths.
\end{abstract}

A total of 733 individuals were collected between 312 and $788 \mathrm{~m}$. Most were distributed in the depth range of $300-500 \mathrm{~m}$ in both surveys. The percentage of females in the samples was $47.5 \%$ in September-October and $54.5 \%$ in April.

A wide size-range, up to maximum total length of $785 \mathrm{~mm}$ in females and $664 \mathrm{~mm}$ in males, was found. The length-weight relationship was calculated for both females and males. Specimens smaller than $300 \mathrm{~mm}$ as well as mature individuals of both sexes were found in both SeptemberOctober 1999 and April 2000. The smallest mature females and males measured 580 and $450 \mathrm{~mm}$, respectively. The size at first maturity was $601 \mathrm{~mm}$ in females. At lengths greater than $510 \mathrm{~mm}$ all males were mature. The percentages of ripe females were $52.8 \%$ in September and $30.3 \%$ in April. The sizes of the embryos ranged from 45 to $220 \mathrm{~mm}$ total length. The relationship between clasper length and total length was computed.

Keywords: Biological sampling, elasmobranch, maturity, Mediterranean Sea

\section{Introduction}

The longnose spurdog Squalus blainvillei (Risso, 1826) is an ovoviviparous demersal shark distributed throughout the Mediterranean down to about $700 \mathrm{~m}$ (Whitehead et al., 1984). Studies on its systematics and biology have been mostly carried out on the Western-Central side of this basin (Ledoux, 1970; Quignard, 1971; Capapé, 1975; Cannizzaro et al., 1995) while on the Eastern side, although its occurrence has long been recorded (Ondrias, 1971; Papaconstantinou and Tortonese, 1980; Papaconstantinou, 1986), the knowledge on its population biology is still rather scanty. Information has been completely lacking in some areas such as the Ionian Sea. The demersal resources of the Italian coast of the Ionian Sea have been investigated for a long time (e.g. Matarrese et al., 1996) but S. blainvillei has never been found. On the contrary, during some surveys to study the deepwater shrimps Aristeus antennatus and Aristaeomorpha foliacea along the Greek coasts of the Ionian Sea, where commercial fishing is only carried at depths down to $400 \mathrm{~m}$, the longnose spurdog was recently found to be abundant.

The increasing investigation of the deep-sea resources (down to $800 \mathrm{~m}$ ) in the Eastern Mediterranean and the fact that sharks are particularly vulnerable to the overexploitation because of their Kselected life-history strategy (Stevens et al., 2000) stimulated the authors to collect basic biological information on elasmobranch species, including S. blainvillei. In fact, shark species could become at risk from fishery if a target fishery for valuable deepwater shrimps develops in the eastern Mediterranean. Thus, the aim of this paper is to provide preliminary information on the distribution, reproduction and population structure of S. blainvillei 
in the Eastern Ionian Sea in order to evaluate its resilience to fishing activity.

\section{Materials and Methods}

Data were collected during two trawl surveys (September-October 1999 and April 2000) carried out in the Eastern Ionian Sea off Northern Greece (Eastern
Mediterranean). The study area was between Kerkira and Zákinthos where trawl fishing only occurs down to $400-500 \mathrm{~m}$ (Fig. 1).

The sampling was carried out between 300 and $1200 \mathrm{~m}$ using a commercial vessel. The nylon bottom otter trawl had a codend of $20 \mathrm{~mm}$ stretched mesh (10 $\mathrm{mm}$ side). The vessel speed, measured using GPS,

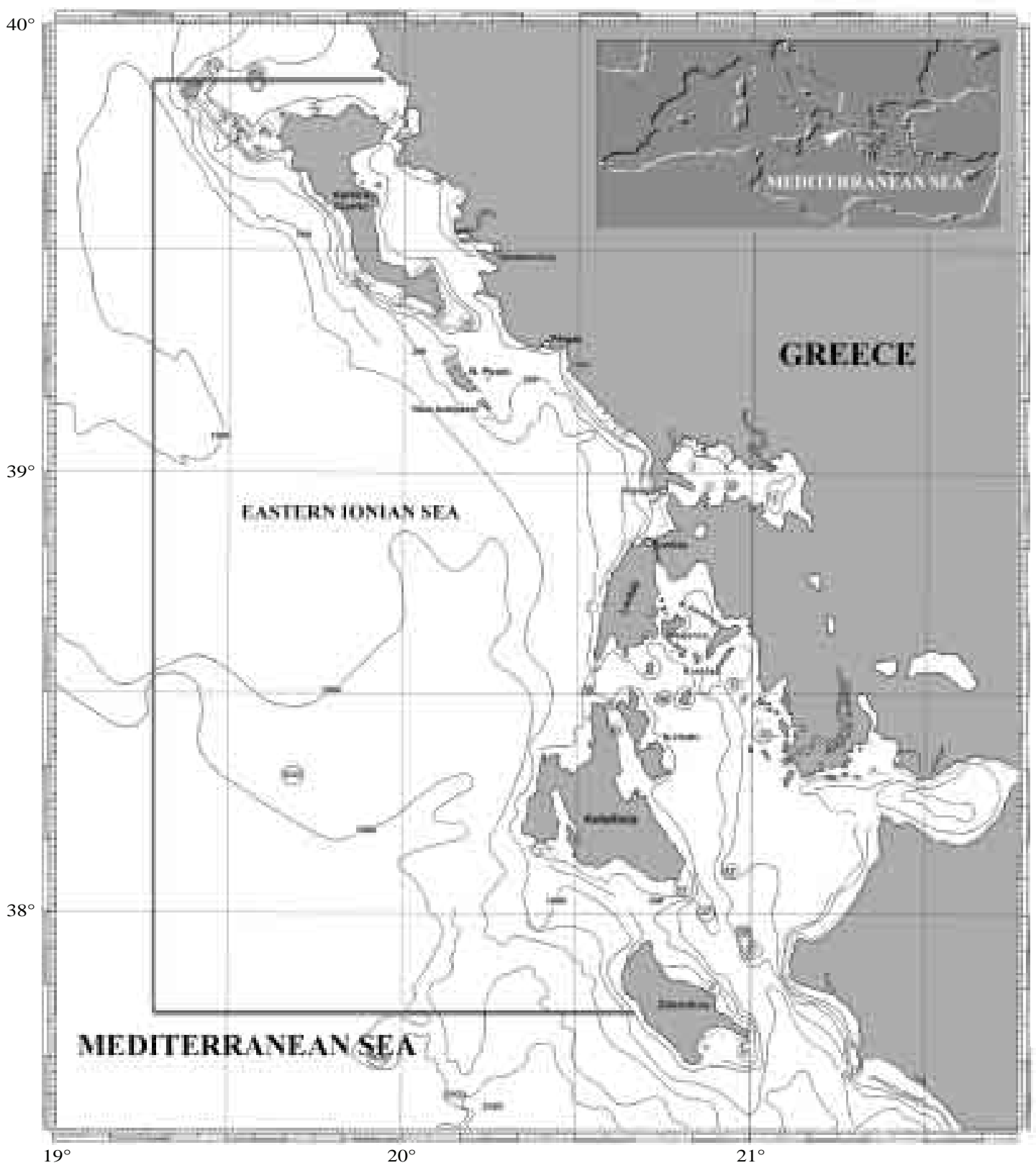

Fig. 1. Map of the investigated area in the Eastern Ionian Sea (Mediterranean Sea). 
was maintained at $2.5-2.8$ knots. Sampling was restricted to daylight hours and the hauls lasted one hour each on average. The number of hauls for each survey and depth stratum and the average number of individuals caught per $\mathrm{km}^{2}$ in each depth stratum are given in the Table 1. The September-October survey was exploratory due to the lack of knowledge of the seabed in the study area. Consequently, the sampling in the $500-700 \mathrm{~m}$ and $700-900 \mathrm{~m}$ depth strata increased in April.

For each specimen of $S$. blainvillei, the total length (TL) to the nearest $\mathrm{mm}$ and the weight (g) were measured. Sex and maturity stage of gonads were determined macroscopically according to Stehmann (1998). For males, clasper length (CL) was taken from insertion to tip to the nearest $\mathrm{mm}$. The relationship between CL and TL was computed by means of linear regression. Statistical differences between changes in the number of females and males between surveys were determined using the G-test (Sokal and Rohlf, 1969). The length-frequency distributions $(20 \mathrm{~mm}$ size classes) of the females and males for each survey were performed. The length/weight relationship for females and males was computed for a subsample according to the power curve function $W=a^{*} T L b$ (using $L n$ transformation) where $a$ is the intersect and $b$ the allometric coefficient (or slope). The linear regression equations for the two sexes were compared statistically using the Chow-test (Koutsoyiannis, 1977). This test verifies if there is a significant difference between both the slope (b) and the intersect (a) of two regression lines estimated from two different samples.

Considering that the proportion of immature individuals in the sampled population might vary monthly, the percentage of ripe individuals in each survey was computed starting from the size at first maturity (the size at which $50 \%$ of the individuals in the population are mature). It was also determined for the pooled data of September-October and April, using the logistic curve showing the percentage of mature specimens by size class.

\section{Results}

Squalus blainvillei was found between depths of 312 and $788 \mathrm{~m}$, most of the population was captured in the $300-500 \mathrm{~m}$ bathymetric stratum $(98.9 \%$ in September-October and $98.6 \%$ in April). Very few individuals were caught between 500-700 $\mathrm{m}$ and 700$900 \mathrm{~m}$ and no individuals were sampled at depths greater than $900 \mathrm{~m}$.

A wide size-range with several modal components was observed in both sexes and surveys. The maximum total lengths in females and males were $785 \mathrm{~mm}$ and $664 \mathrm{~mm}$, respectively (Fig. 2). Small specimens $(<300$ $\mathrm{mm}$ ) were collected in both surveys. The smallest individuals of both sexes measured $190 \mathrm{~mm}$ TL. They were without external yolk sac. In both females and males, significant differences were found between the length-frequency distributions calculated in the two surveys (females: Diff. $0.35>0.18 ; p<0.01$; males: Diff.0.31 $>0.19 ; p<0.01)$.

The weight of females ranged from 47 to $2666 \mathrm{~g}$ and males weighed between 38 and $970 \mathrm{~g}$. The sizeweight relationship was computed for the total length (TL) expressed in millimetres and body weight (W) in grams. The functions were as follows:

$$
\begin{array}{ll}
\text { Females: } & W=0.000001018^{*} T L^{3.25}, \\
& r=0.994, n=112 \\
\text { Males: } & W=0.000001746^{*} T L^{3.16}, \\
& r=0.986, n=67
\end{array}
$$

The Chow-test gave significant differences between the length-weight relationship of the two $\operatorname{sexes}\left(F^{*}=3.66, p<0.01\right)$.

The sex ratio was around $50 \%$ in both SeptemberOctober and April. Differences in the number of females and males by cruise were not significant (G1 $=2.95, p>0.05$ ).

The smallest mature females and males measured 580 and $450 \mathrm{~mm}$ respectively (Fig. 3 and 4). The size

TABLE 1. Number of hauls and the average number of individuals caught per $\mathrm{km}^{2}$ in each survey and each depth stratum.

\begin{tabular}{lccrrr}
\hline \hline \multirow{2}{*}{$\begin{array}{c}\text { Depth } \\
\text { Stratum }(\mathrm{m})\end{array}$} & Surface & \multicolumn{2}{c}{ Sept-Oct 1999 } & \multicolumn{2}{c}{ April 2000 } \\
Area $\left(\mathrm{km}^{2}\right)$ & N. hauls & N/km & N. hauls & N/km² \\
\hline $300-500$ & 933 & 19 & 300 & 17 & 135 \\
$500-700$ & 762 & 6 & 7 & 17 & 1 \\
$700-900$ & 764 & 3 & 5 & 13 & 1 \\
$>900$ & & 4 & & 4 & \\
\hline
\end{tabular}




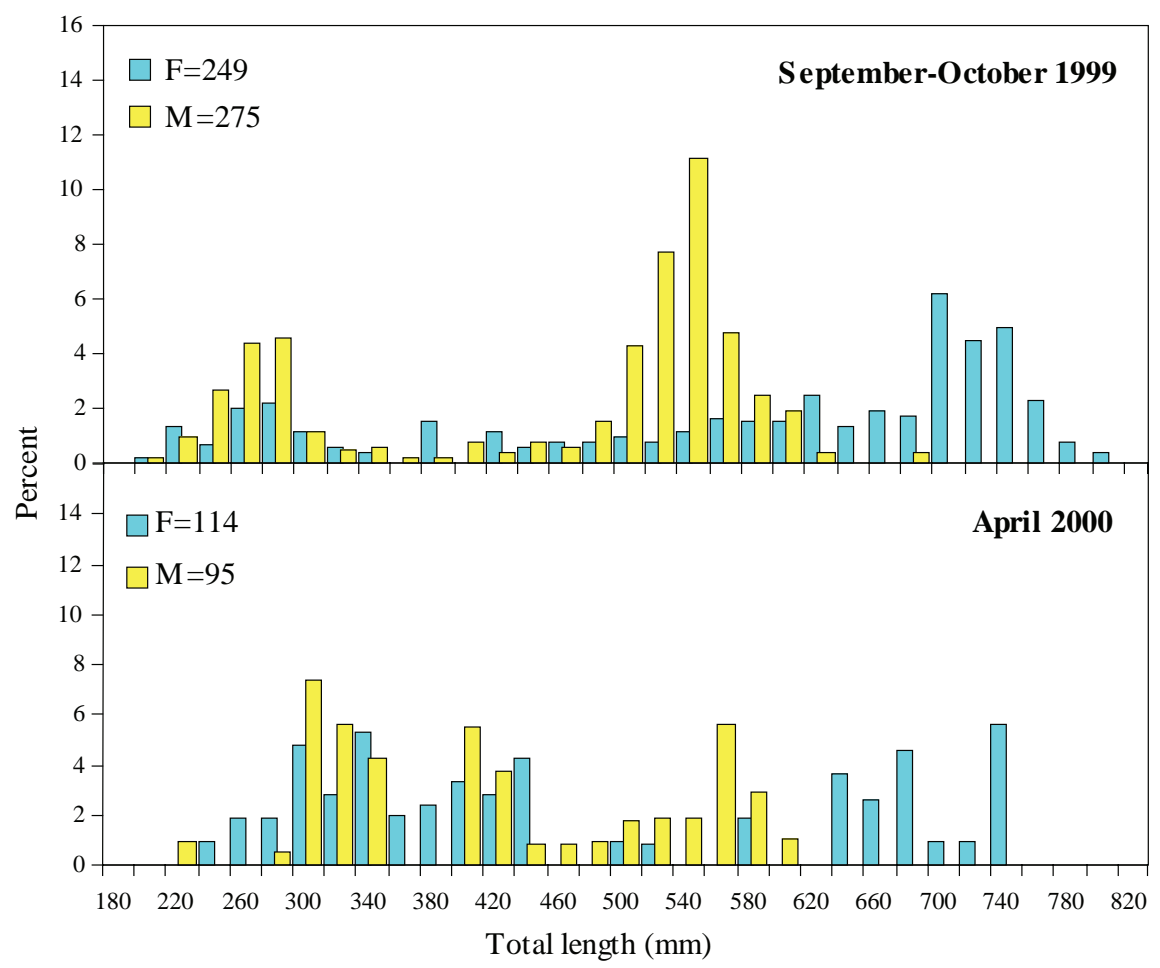

Fig. 2. Length-frequency distribution, by sex, of Squalus blainvillei caught along Greek coasts of the northern Ionian Sea during SeptemberOctober 1999 and April 2000.

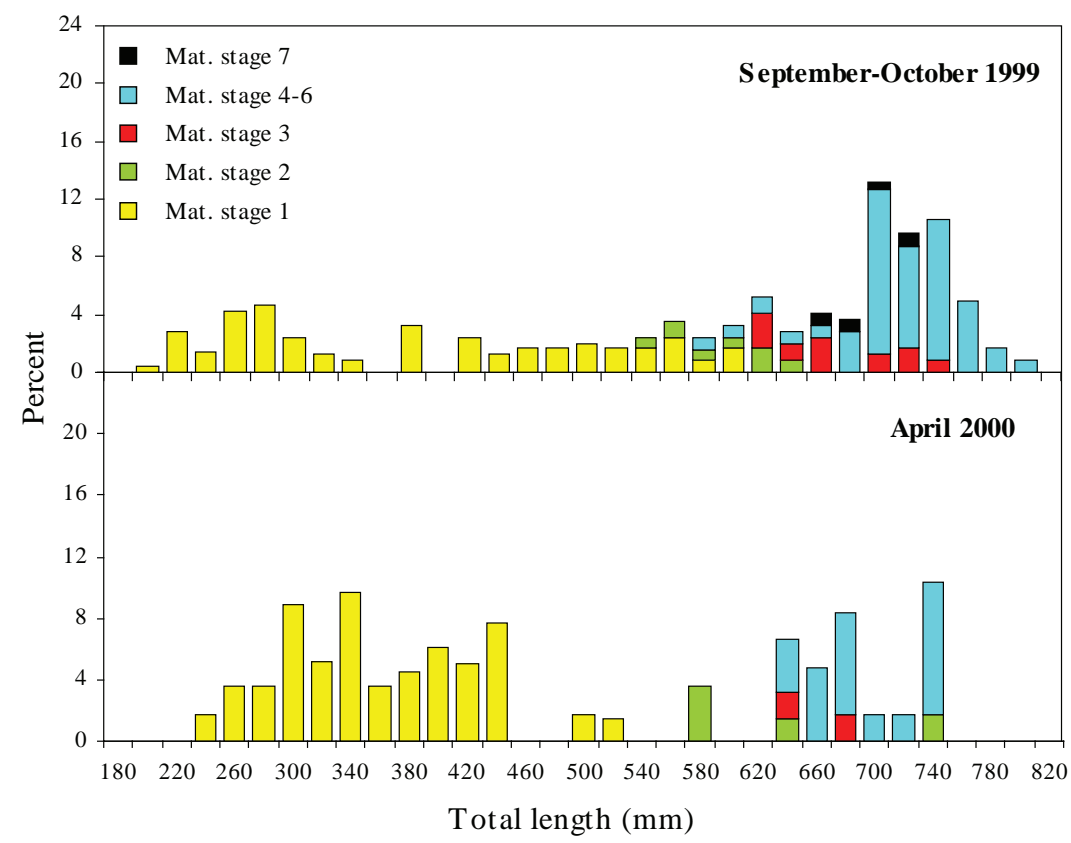

Fig. 3. Length-frequency distributions by maturity stage of gonads of Squalus blainvillei females caught along Greek coasts of the northern Ionian Sea during September-October 1999 and April 2000 . 


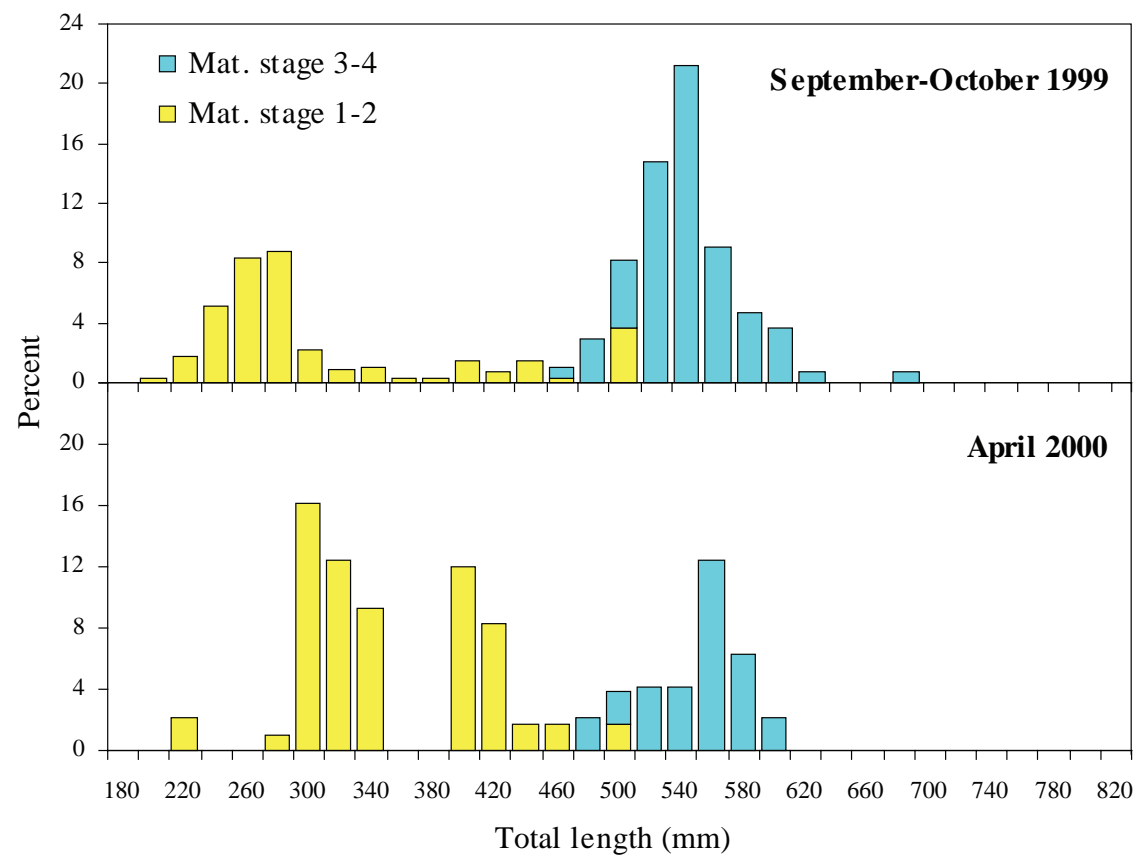

Fig. 4. Length-frequency distributions by maturity stage of gonads of Squalus blainvillei males caught along Greek coasts of the northern Ionian Sea during September-October 1999 and April 2000.

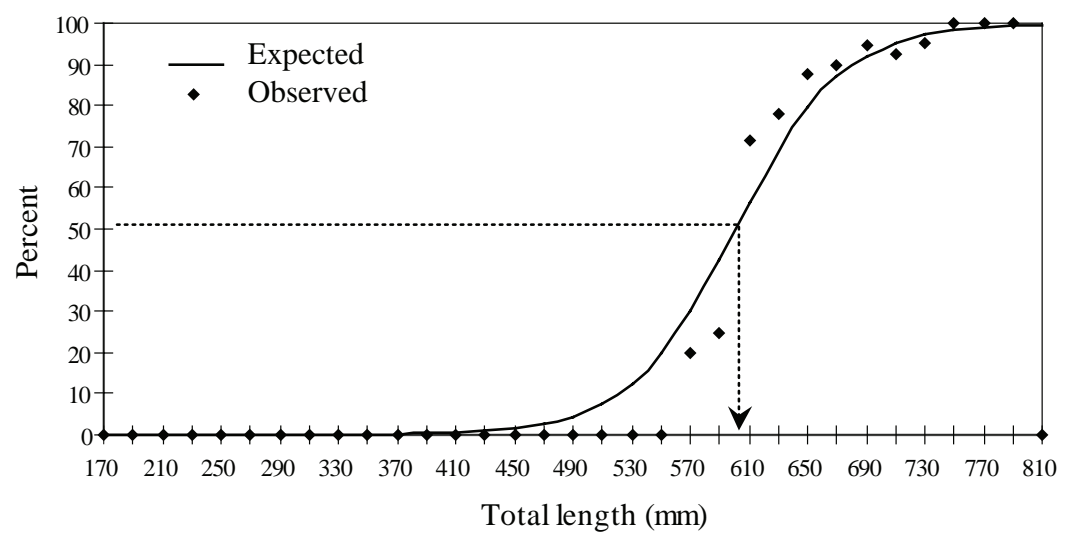

Fig. 5. Expected and observed percentage by size of females of Squalus blainvillei caught along Greek coasts of the northern Ionian Sea during September-October 1999 and April 2000, with indication of size at first maturity $\left(L_{50}\right)$.

at first maturity in females was $601 \mathrm{~mm}$ (Fig. 5). The data for males did not fit any reliable logistic function preventing the calculation of the size at first maturity. In fact, at lengths greater than $510 \mathrm{~mm}$ all males were mature. The percentages of ripe females were $97.1 \%$ in September-October and $100 \%$ in April. The percentages of mature males were $60.2 \%$ and $33.2 \%$ in the former and latter survey, respectively. In stage 5 and 6 females, the uteri contained from 2 to 6 embryos. Their sizes ranged from 45 to $220 \mathrm{~mm}$ TL. The size-range in the embryos found during September-October (45-220 mm TL) was wider than in April (117-220 mm TL) (Fig. 6). All these embryos had yolk sacs. 


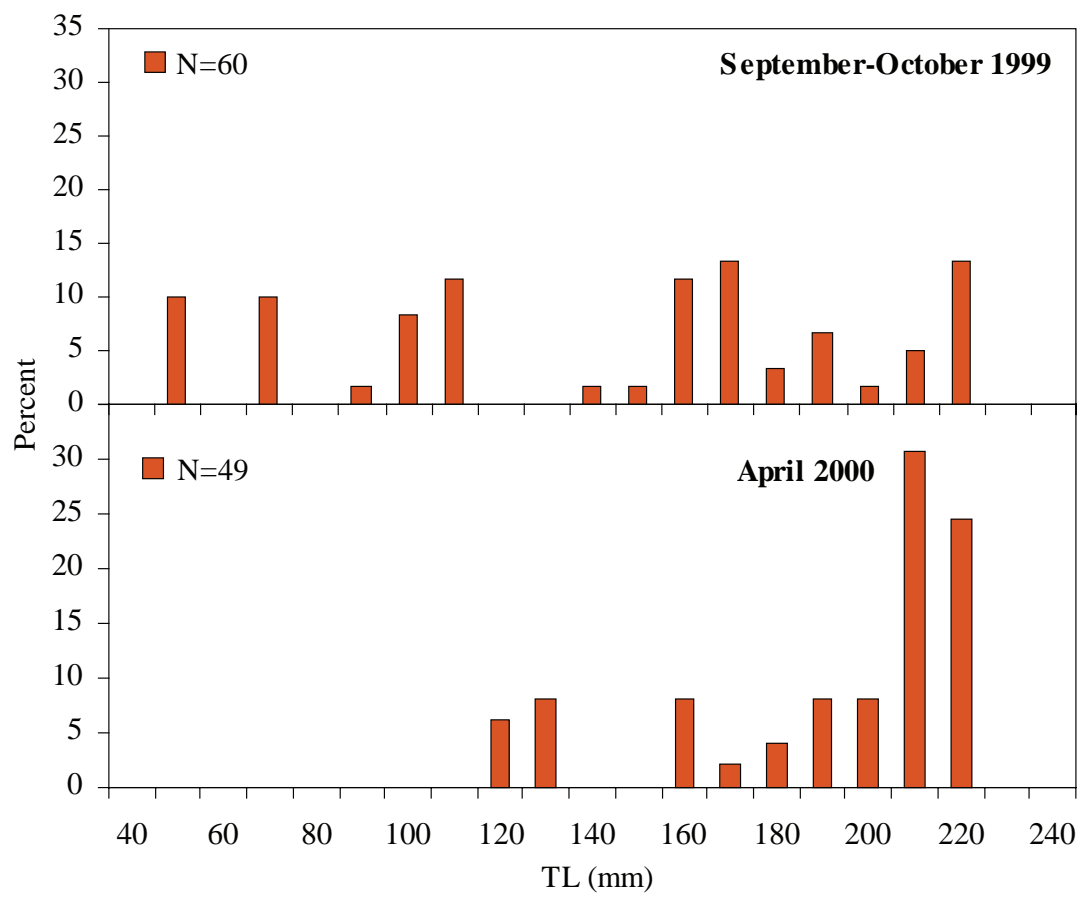

Fig. 6. Length-frequency distribution of embryos of Squalus blainvillei caught along Greek coasts of the northern Ionian Sea during September-October 1999 and April 2000.

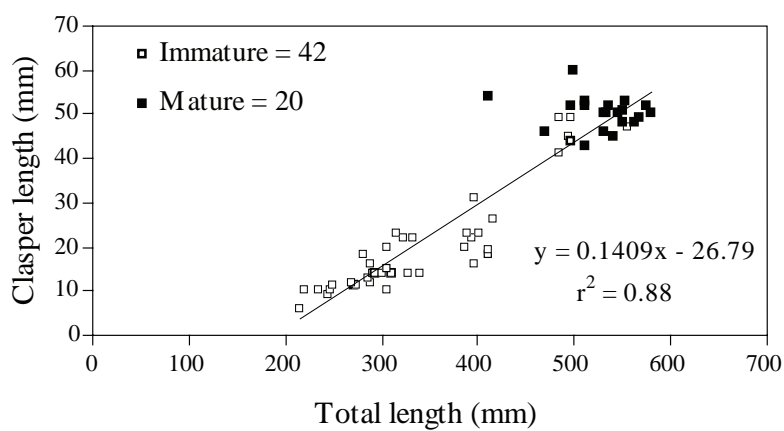

Fig. 7. The linear regression plot between clasper length and total length of Squalus blainvillei, with indication of immature and mature males.

The relationship between CL and TL is given by the equation: $C L=-26.79+0.14 \mathrm{TL} ; r^{2}=0.88 ; n=$ 62. The linear regression plot, with an indication of immature and mature males, is shown in Fig. 7. Although a significant regression was computed, two clusters appear to be evident for the whole process, namely the length of claspers increases with size in immature specimens, while it showed similar values for different sizes in mature individuals.

\section{Discussion}

Although a wider depth range was sampled during the two surveys, the longnose spurdog was mostly distributed between $300-500 \mathrm{~m}$. This is in agreement with other observations in the Mediterranean (Quignard, 1971; Papaconstantinou and Tsimenides, 1979; Cannizzaro et al., 1995). Although sex and size segregation in shark populations are well known and are considered to be a mechanism for avoiding cannibalism both for pelagic and demersal species (Springer, 1967), the present study indicates that there is no segregation of the longnose spurdog by depth or size. Reproductive adults were found together with juveniles in the same samples. Cannizzaro et al. (1995) found both juveniles and adults down to 565 $\mathrm{m}$ in depth. No data on cannibalism was reported for this species by Quignard (1971) and Capapé (1975).

Sizes at maturity for sharks examined in this study are in agreement with previous studies (Quignard, 1971; Cannizzaro et al., 1995). The development process of claspers confirms male maturation. The litter size was also in agreement with Quignard (1971). Although the largest embryos measured up to $220 \mathrm{~mm}$ TL and had a yolk sac, the size at birth might 
be around $190 \mathrm{~mm}$, confirming the observations of Ranzi (1932), since the smallest specimens collected in the sampled population measured $190 \mathrm{~mm}$ TL and were found to be without a yolk sac.

Since only two surveys were considered in this study, it is not possible to make conclusions about the seasonal cycle of reproduction. However, the occurrence of mature females and males, and the young-of-the-year in both September-October and April would confirm a prolonged reproductive period during the year (Quignard, 1971; Cannizzaro et al., 1995). Continuous reproductive activity is known for other species of deep-sea sharks, both in the Mediterranean (e.g. Tursi et al., 1993) and elsewhere (e.g. Yano and Tanaka, 1988; Girard and Du Buit, 1999). Considering the vulnerability of sharks to overfishing (e.g. Stevens et al., 2000), such protracted period of reproduction throughout the year could make up for the late maturity and low fecundity as far as the survival strategy of the species is concerned. However, the distribution of both juveniles and mature individuals, at the same depths where exploitation of deep-water shrimps might develop off Greece, indicates the need for management strategies to mitigate the undesirable effects of $S$. blainvillei overexploitation.

\section{Acknowledgements}

This work was supported by European Commission in cooperation with the Italian and Greek governments as part of the "INTERREG II ItalyGreece" project.

\section{References}

CANNIZZARO, L., P. RIZZO, D. LEVI, and S. GANCITANO. 1995. Age determination and growth of Squalus blainvillei, (Risso, 1826). Fish. Res., 23: 113-125.

CAPAPÉ, C. 1975. Etude du régime alimentaire de Squalus blainvillei (Risso, 1826) des côtes tunisiennes. Bull. Inst. Natl. Sci. Tech. Océanogr. Pêche Salammbô, 4: 61-73.

GIRARD, M., and M.H. DU BUIT. 1999. Reproductive biology of two deep-water sharks from the British Isles, Centroscymnus coelolepis and Centrophorus squamosus (Chondrichthyes: Squalidae). J. Mar. Biol. Ass. U.K., 79: 923-931.

KOUTSOYIANNIS, A. 1977. Theory of econometrics: an introductory exposition of econometric methods. Hong Kong: Macmillan Press Ltd.

LEDOUX, J. C. 1970. Affinités et origines du Squalus blainvillei de Méditerranée. J. Ichthytol., pp. 65-69.

MATARRESE, A., G. D'ONGHIA, A. TURSI, and M. BASANISI. 1996. New information on the Ichthyofauna of the South-Eastern Italian coasts (Ionian Sea). Cybium, 20(2): 197-211.

ONDRIAS, L.C. 1971. A list of the fresh and sea water fishes of Greece. Hellenic Oceanol. Limnol., 7: 13-14.

PAPACONSTANTINOU, C. 1986. The ichthyofauna of Korinthiakos and Patraikos Gulfs and the Ionian Sea. Biol. Gallo-Hell., 12: 229-236.

PAPACONSTANTINOU, C., and E. TORTONESE. 1980. On a collection of fishes from the Thermaikos Gulf (N.E. Greece). Thalassographica, 3(2): 15-42.

PAPACONSTANTINOU, C., and N. TSIMENIDES. 1979. Some uncommon fishes from the Aegean Sea. Cybium, 7: 3-14.

QUIGNARD, J. P. 1971. Recherches sur la biologie de Squalus blainvillei (Risso, 1826). Trav. Lab. Biol. Halieutique Univ. Rennes, 5: 125-141.

RANZI, S. 1932. Le basi fisio-morfologiche dello sviluppo embrionale dei Selaci 1. Pubb. St. Zool. Napoli, 12(2): 209-290, 45 fig.

SOKAL, R. R., and F. J. ROHLF. 1969. Biometry: W.H. Freeman and Co., San Francisco, 776 p.

SPRINGER, S. 1967. Social organization of shark populations. In: Sharks, Skates and Rays. P.W. Gilbert, R.F. Mathewson and D.P. Rall (eds). Baltimore, MD: Johns Hopkins Press, p. 149-174.

STEHMANN, M. 1998. Revised maturity scale for sharks, rays and chimaerids. In: EC FAIR Project CT 95-0655. Document, No. 40, p. 17-21.

STEVENS, J. D., R. BONFIL, N. K. DULVY, and P. A. WALKER. 2000. The effects of fishing on sharks, rays, and chimaeras (chondrichthyans), and the implications for marine ecosystems. ICES J. Mar. Sci., 57: 476-494.

TURSI, A., G. D'ONGHIA, A. MATARRESE, and G. PISCITELLI. 1993. Observations on population biology of the blackmouth catshark Galeus melastomus Rafinesque, 1810 (Pisces, Scyliorhinidae) in the Ionian Sea. Cybium, 17(3): 187-196.

WHITEHEAD, P. J. P., M. L. BAUCHOT, J. C. HUREAU, J. NIELSEN, and E. TORTONESE. 1984. Fishes of the North-Eastern Atlantic and the Mediterranean (FNAM). Vol. 1-3: Unesco, Paris, 1473 p.

YANO, K., and S. TANAKA. 1988. Size at maturity, reproduction cycle, fecundity, and depth segregation of the deep sea squaloid sharks Centroscymnus owstoni and Centroscymnus coelolepis in Suruga Bay, Japan. Nippon Suisan Gakkaishi, 54: 167-174. 